\title{
Newer Generation of Scooters: Polychlorinated Dibenzo-p-dioxin and Dibenzofuran and Polychlorinated Biphenyl Reductions
}

\author{
Hung-Hong Chen ${ }^{1}$, Yun-Hwei Shen ${ }^{1 * *}$, Hsi-Hsien Yang ${ }^{2}$, Jau-Huai Lu ${ }^{3}$, Lin-Chi Wang ${ }^{4 *}$, \\ Yen-Kung Hsieh $^{5 * *}$, Chia-Fon Lee ${ }^{6}$, Sheng-Lun Lin ${ }^{7,8^{*}}$ \\ ${ }^{1}$ Department of Resources Engineering, National Cheng Kung University, Tainan 70101, Taiwan \\ ${ }^{2}$ Department of Environmental Engineering and Management, Chaoyang University of Technology, Taichung 41349, \\ Taiwan \\ ${ }^{3}$ Department of Mechanical Engineering, National Chung Hsing University, Taichung 40254, Taiwan \\ ${ }^{4}$ Department of Environmental Engineering, Chung Yuan Christian University, Taoyuan 32023, Taiwan \\ ${ }^{5}$ Marine Ecology and Conservation Research Center, National Academy of Marine Research, Kaohsiung 80661, Taiwan \\ ${ }^{6}$ Department of Mechanical Science and Engineering, University of Illinois at Urbana-Champaign, IL 61801, USA \\ ${ }^{7}$ Department of Civil Engineering and Geomatics, Cheng Shiu University, Kaohsiung 83347, Taiwan \\ ${ }^{8}$ Center for Environmental Toxin and Emerging-Contaminant Research, Cheng Shiu University, Kaohsiung 83347, \\ Taiwan
}

\begin{abstract}
Scooter emissions have attracted attention in recent years because of human exposure to their direct effects in urban areas. Trace toxics, such as polychlorinated dibenzo- $p$-dioxins and dibenzofurans (PCDD/Fs) and polychlorinated biphenyls (PCBs) have thus become important in scooter emissions. In this work, ten Tier 5 and 6 scooters were tested using a 100-second model to analyze their PCDD/F and PCB emissions and compare the results with previous Tier 3 studies. Tier 5 and 6 scooters emitted 1.86-2.91 and 0.133-0.298 pg WHO-TEQ Nm ${ }^{-3}$ of PCDD/Fs and PCBs, respectively. It was interesting to find that the PCDD/Fs were reduced by $94.6-97.4 \%$ and $99.4-99.6 \%$ in Tier 5 and 6 motors, respectively. The congener profiles of PCDD/Fs were affected by improving the emission control. The domination of highly chlorinated congeners shown in Tier 3 was reduced in Tier 5 with increases in low chlorinated PCDFs. This showed that de novo synthesis occurred and could be inhibited by the OBD system in Tier 6. The tailpipe renews reduced 60.0-93.8\% of PCDD/Fs and 85.3-97.7\% of PCB emissions, but several cases would still exhibit a delay for stable operation of a catalytic converter. The annual emissions of PCDD/F TEQ was calculated based on the statistics in 2019 and tested as $1.63 \mathrm{~g}$ WHO-TEQ. It could be $99.7 \%$ reduced to $3.55 \mathrm{mg}$ by replacing all scooters with Tier 6. Consequently, the improvement of electronic fuel injection and onboard diagnostics systems from a carburetor without feedback control not only reduced the regulated pollutants but effectively reduced PCDD/F emissions.
\end{abstract}

Keywords: Scooter; PCDD/Fs; PCBs; Electronic fuel injection; on-board diagnostics; Carburetor; Emission standards.

\section{INTRODUCTION}

The rapid economic development and increasing population

\footnotetext{
* Corresponding author.

Tel.: +886-3-2654913

E-mail address: lcwang@cycu.edu.tw (L.C. Wang)

* Corresponding author.

Tel.: +886-7-7358800 ext. 2605; Fax: +886-7-733-2204

E-mail address: cbmsgml@gmail.com (S.L. Lin)

** Corresponding author.

E-mail address: yhshen@mail.ncku.edu.tw (Y.H. Shen); yk886963@gmail.com (Y.K. Hsieh)
}

leads to more environmental impact by human activities. The relative health risks are in terms of pollutant emission especially in the urban area (Goel and Guttikunda, 2015; Grivas et al., 2018; Wu et al., 2020). The highly intensive and complex industrial activities, the traffic emission is also an important contributor of urban atmospheric pollutants, including carbon monoxide (CO), hydrocarbons ( $\mathrm{HC})$, and nitrogen oxides $\left(\mathrm{NO}_{\mathrm{x}}\right)$ (Cheng et al., 2018, Tsai et al., 2019a), and other toxic pollutants in the urban atmosphere (Grivas et al., 2018, Dhital et al., 2019). The volatile organic carbons (VOCs) emissions are also concerned in the densely populated urban area (Tsai et al., 2018b). They could be contributed by both human life activity (Que et al., 2019) and locally traffic emission, when the secondary pollutants subsequently occurs from the atmospheric chemical reactions 
and remained in the air around the residents (Liu et al., 2017; Liu et al., 2020; Wu et al., 2020). Particulate matter (PM) pollution attracted more consideration from environmental and public health researchers. The physical and chemical characteristics of PM and their containing chemicals (e.g., heavy metals, air toxins, acids) could directly affect the human health (Tsai et al., 2018a; Lin et al., 2019b; Tsai et al., 2019a; Zhang et al., 2019). Ultrafine particle also becomes a recent issue for more deeply health effect on the respiratory system of the urban residents (Grana et al., 2017, Xiang et al., 2018, 2019). Fortunately, most of the gaseous pollutants and PM from on-road vehicles could be measured (or monitored) by either standard method certified by EPA, the consumergrade air pollution measurement devices (Manibusan and Mainelis, 2020; Park et al., 2020), or even portable monitors. The control strategy could be approached smoothly, while the emerging measures could be on time. The only challenge of pollution issues would be that they cannot quantify some pollutants in a quick time. Unfortunately, those pollutants are usually more persistent and even toxic, such as polyaromatics and their halogenated compounds (Durant et al., 1996, 1999; Chen et al., 2018).

Polychlorinated dibenzo- $p$-dioxins and dibenzofurans (PCDD/Fs) and polychlorinated biphenyls (PCBs) are semivolatile organic compounds (SVOCs) that could spread out in various media. They are considered as two important groups of persistence organic pollutants (POPs), which have a long half-life in the environment (Pirkle et al., 1989, Sinkkonen and Paasivirta, 2000) and even in the human body (Flesch-Janys, 1996; Gao et al., 2019). International Agency for Research on Cancer (IARC) classify 2378TeCDD in Group 1 (carcinogenic to human), when the other PCDD/Fs and dioxin-like PCBs (dl-PCBs) were probable human carcinogens (IARC, 1997; Iwata et al., 2004; IARC, 2016). They are reported to have enzyme induction and endocrine effect (Li and Hansen, 1996), bioaccumulation, and magnification in many organisms. This persistence property led to spread widely around the world even in the place off the beaten track (Booth et al., 2013; Vecchiato et al., 2015; Corsolini et al., 2017; Ssebugere et al., 2019). Therefore, the $\mathrm{PCDD} / \mathrm{F}$ and $\mathrm{PCB}$ exposures attracted prominent concern.

$\mathrm{PCDD} / \mathrm{Fs}$ and PCB were mainly emitted from waste incinerators, metallurgical processes, fossil fuel power plants, boilers, cement plants, and open burning when the on-road transport is a less contribution for PCDD/Fs and PCBs in most of the countries (Bawden et al., 2004; Quass et al., 2004; Lohmann et al., 2007; Wang et al., 2012). In Taiwan, the total annual PCDD/F emissions have been reduced by $83.8 \%$ from $329.5 \mathrm{~g}^{-T E Q ~} \mathrm{yr}^{-1}$ in 2002 to $53.3 \mathrm{~g}^{-T E Q ~} \mathrm{yr}^{-1}$ in 2016 (Tu, 2018). The dominant emission sources were changed from the electric arc furnace $(54.6 \%)$, waste incinerators $(19.4 \%)$, and sinter plant $(11.4 \%)$ in 2002 to the boiler combustion $(23.6 \%)$, electric arc furnace $(22.1 \%)$, sinter plant $(17.7 \%)$, waste incinerators $(10.0 \%)$, non-ferrous metal secondary smelting processes $(9.6 \%)$, and fugitive sources $(6.9 \%)$ in 2012 and remained the similar flat-distribution of PCDD/F sources until today. This could be resulted from that the stricter emission standards for specific stationary sources were established within 2003-2010. The PCDD/F emission seems to be well controlled in Taiwan. However, the real near-ground exposure levels of $\mathrm{PCDD} / \mathrm{Fs}$ and $\mathrm{PCBs}$ were still not clear, especially the peak value occurred by traffic sources, since they could not be online continuous monitored and could increase the potential health risk in the urban area (Oehme et al., 1991; Broz et al., 2000; Chuang et al., 2010, Wheatley and Sadhra, 2010). More recently, the level of contribution of exhaust emissions from scooters and scooters to the contamination of ambient air was reported by $30 \%$ in Rome City (Grana et al., 2017). A latest report showed there were $28 \%$ of $\mathrm{PCDD} / \mathrm{F}$ came from traffic emissions in Busan, which is a heavily industrialized and densely populated city in South Korea (Jang et al., 2020). There are still no regulations on $\mathrm{PCDD} / \mathrm{F}$ and $\mathrm{PCBs}$ emissions from mobile sources, while several studies have reported the technologies to reduce their emissions.

The scooters could be considered a major contributor to traffic-related emissions in Asian cities (Chiang et al., 2014; Macedo et al., 2017; Hu et al., 2018). There are over 350 million scooters around the world and keep increasing with the rise of the metropolitan population (Chiang et al., 2014; Alves et al., 2015; Chernyshev et al., 2018). Among the global distribution of scooters, Asia is overriding followed by Europe, Latin America, North America, and Africa (DeMarini et al., 2004; Costagliola et al., 2014; Costagliola et al., 2016). Scooters are more flexible and convenient, especially in urban areas where traffic is intensively crowded (Durant et al., 1996, 1999). In recent years, the emission from the old model scooter was considered as the major source of air pollutants. It is expected to grow at a faster rate with no strategy to scrap off the older scooters (Alves et al., 2015; TWEPA, 2020), which contributes more regulated and unregulated pollutants related to environmental and human health because of their poor combustion quality. Besides, the two-stroke scooter was not performed ideal air-fuel ratio and led to higher air pollutant emission (Prati et al., 2011; Yao et al., 2013; Platt et al., 2014; Tsai et al., 2017; Tsai et al., 2020).

In Taiwan, the number of scooters slightly decreased from 15.9 million in 2010 to 14.0 million in 2019 (TWEPA, 2020). Unfortunately, the density of the resident population remained very high in the major city (e.g., 9,732 people $\mathrm{km}^{-2}$ in Taipei City), when the scooter density was also higher 3,232 than most of the cities around the world (as shown in Fig. 1). The raising health risk by the exposure of tailpipe emissions could be then expectable. Today, the treatment technologies for $\mathrm{HC}, \mathrm{CO}, \mathrm{NO}_{\mathrm{x}}, \mathrm{VOC}$, and PM (Dhital et al., 2019, Tsai et al., 2019b) were improved along with the generations of scooter emission standards (Tier 1 to Tier 6). Fig. 1 also shows the amount of Tier $1+2+3$ scooter decreased, when the Tier 4 and 5 scooters dominates the onroad vehicle emissions, leading to lower regulated pollutant levels. Fortunately, the motors fit Tier 6 and 7 (established in 2021) would increase. However, the unregulated toxic pollutants, such as PCDD/Fs and PCBs, were not showed to be simultaneously reduced by upgrading the older vehicles to the newer generations.

Therefore, this study focuses on the comparison of the $\mathrm{PCDD} / \mathrm{F}$ and PCB emissions between Tier 3- and Tier 5scooters, which have different fuel-feeding systems. Four- 


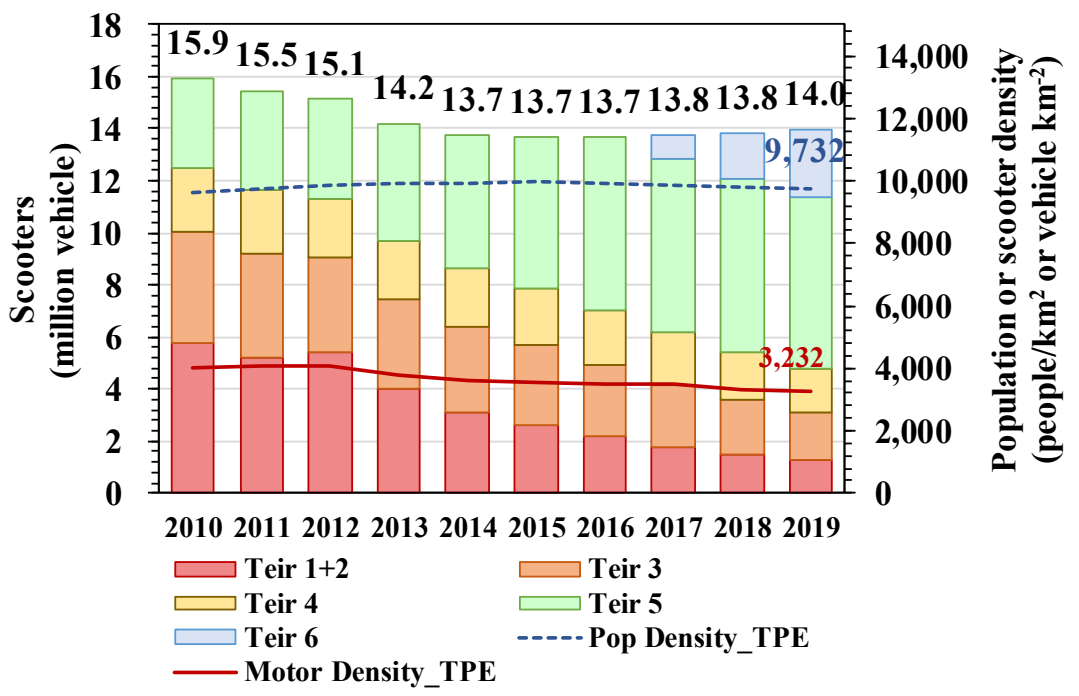

Fig. 1. The amount and density of population and various-generation scooters in Taiwan.

and two-stroke Tier 3 engines were also discussed for their different emissions. The effectivity of new fuel injection and treatment system on $\mathrm{PCDD} / \mathrm{F}$ and $\mathrm{PCB}$ reductions were eventually confirmed.

\section{MATERIALS AND METHODS}

\section{Tested Scooters}

There were thirty scooters selected from three leading brands (over 90\% market share) in Taiwan, selected as the tested vehicles in the current research. They all had 4-stroke (4-ST), $125 \mathrm{~cm}^{3}$ displacement, and electronic fuel injection engines, which were manufactured in 2016, fitting the Tier 5 and Tier 6 emission standards (as shown in Table 1). The major improvement to approach the stricter emission standards from Tier 3 to 5 was replacing the carburetor by electronic fuel injection (EFI) system, when the on-board diagnostics with an $\mathrm{O}_{2}$ sensor $\left(\mathrm{OBD} / \mathrm{O}_{2}\right)$ was further added into Tier 6 scooter. These improvements would lower the pollutants in the exhaust. The testing fuels used in this study were provided by Chinese Petroleum Corporation. Their benzene, sulfur, and oxygen contents were $0.8 \mathrm{vol} \%, 10 \mathrm{mg} \mathrm{kg}^{-1}$, and $2.7 \mathrm{wt} \%$, respectively, as well as the fuel-containing aromatic and toxic substances were limited. For Tier 5 (abbr. T5) /Tier 6 (abbr. T6), the limits of $\mathrm{CO}, \mathrm{HC}$, and $\mathrm{NOx}$ were tightened to $2.0 / 1.14,0.8 / 0.38$ and, and $0.15 / 0.07 \mathrm{~g} \mathrm{~km}^{-1}$, respectively, while the advanced electronic fuel injection system and on-board diagnostics (OBD) with $\mathrm{O}_{2}$ sensor were equipped. The specifics of compared scooters selected from the previous studies were also listed in Table 1, includes six Tier 3, 4-stroke scooters (abbr. R3-4ST), and other six Tier 3, 2-stroke ones (abbr. R3-2ST). Besides, we investigated the emission effect of renewing the tailpipe from each brand of scooter. The replacement took place after the driving cycle, introduced in the following section tests for the older ones.

\section{Dynamometer and Gaseous Pollutant Monitoring}

The overall testing system for the current research could be classified into three parts, dynamometer unit, sampling unit, and vacuum system, which are illustrated in Fig. 2. The dynamometer unit is composed of an AXIS DYNO MOTO VX-12 $(290 \mathrm{~cm} \times 96.5 \mathrm{~cm} \times 127 \mathrm{~cm})$, a controlling computer, and the tested scooters. The maximum testing power, torque, and speed were $180 \mathrm{hp}, 136 \mathrm{~kg}-\mathrm{m}$, and $262 \mathrm{~km} \mathrm{~h}^{-1}$, respectively, when the system could be driven by $12 \mathrm{~V} / 60 \mathrm{~Hz}$ electricity power.

The standard locomotive testing driving cycle in Taiwan is Urban Driving Cycle (UDC), which is a part of New European Driving Cycle (NEDC). This study further simplified the UDC to a 100 -second model, which included $29.70 \%$ idling, $24.75 \%$ acceleration, $18.81 \%$ cruising, and $26.73 \%$ deceleration periods. This model operated all tested scooters, while the 100 -second emission data of regulated pollutants, PCDD/F, and PCBs were simultaneously collected from an extended stack connected to the tailpipe of each scooter (as shown in Fig. 2). The gaseous pollutants were then monitored by an emission analyzer (HORIBA MEXA584L), which used a non-dispersive infrared (NDIR) sensor for $\mathrm{CO}\left(0.00-10.00 \%\right.$ vol.), $\mathrm{HC}(0-10,000 \mathrm{ppmv})$, and $\mathrm{CO}_{2}$ (0.00-20.00\% vol.), as well as a yttrium-stabilized $\mathrm{ZrO}_{2}$ (YSZ) electrochemical sensor for $\mathrm{NO}_{\mathrm{x}}(0-5,000 \mathrm{ppmv})$ and $\mathrm{O}_{2}(0.00-25.00 \mathrm{vol} \%)$ on-line monitoring. The precisions of $\mathrm{CO}, \mathrm{HC}$, and $\mathrm{CO}_{2}$ sensors were $\pm 0.01 \%$ vol., $\pm 3.3 \mathrm{ppmv}$, and $0.17 \%$ vol., respectively.

\section{Sampling and Analyzes of PCDD/Fs and PCBs}

An isokinetic flue gas sampling procedure referred to USEPA Method 23A and NIEA A808.75 was used to collect the PCDD/F and PCB samples from an extended stack connected with the scooters' tailpipes. The sampling train and vacuum system is illustrated in Fig. 2. The particulate phase of PCDD/Fs and PCBs were collected by a 70-mm quartz fiber filter paper (Pallflex $\left.{ }^{\circledR}\right)$, which was pretreated by heating to $400^{\circ} \mathrm{C}$ for 6 hours with a high-temperature furnace and storage in electronic desiccator ( $47 \%$ relative humidity) for 24 hours before being weighed by an electronic balance (model CP225D, five-digit balance manufactured by Sartorius) to eliminate the interference of background medium. The 
Table 1. Specifications of testing and referenced scooters.

\begin{tabular}{|c|c|c|c|c|c|}
\hline $\begin{array}{l}\text { Scooters type } \\
\text { (amounts of samples) }\end{array}$ & Brand A $(n=4)$ & Brand B $(\mathrm{n}=3)$ & Brand C $(\mathrm{n}=3)$ & R3-4ST $(n=6)$ & R3-2ST $(n=6)$ \\
\hline Engine type & 4-stroke & 4-stroke & 4-stroke & 4-stroke & 2-stroke \\
\hline Year of manufacture & 2016 & 2016 & 2017 & 1998-2001 & 2003-2004 \\
\hline Displacement $\left(\mathrm{cm}^{3}\right)$ & 125 & 125 & 125 & $50,100,125$ & 50,100 \\
\hline Fuel feeding system & $\mathrm{EFI}^{1}$ & $\mathrm{EFI}^{1}$ & $\mathrm{EFI}^{1}$ & Carburetor & Carburetor \\
\hline Mileage $(\mathrm{km})$ & $8,098-29,564$ & $7,235-20,392$ & $6,668-26,363$ & $2,788-10,919$ & $17,077-49,956$ \\
\hline \multirow[t]{3}{*}{$\mathrm{APCS}^{2}$} & $\mathrm{PUFF}^{3}$ & $\mathrm{PUFF}^{3}$ & $\mathrm{PUFF}^{3}$ & $\mathrm{NFF}^{4}$ & $\mathrm{NFF}^{4}$ \\
\hline & $\mathrm{TWC}^{5}$ & $\mathrm{TWC}^{5}$ & $\mathrm{TWC}^{5}$ & & \\
\hline & & & $\mathrm{OBD} / \mathrm{O}_{2}$ & & \\
\hline Emission standard & Tier 5 & Tier 5 & Tier 6 & Tier 3 & Tier 3 \\
\hline $\mathrm{CO}, \mathrm{gkm}^{-1}$ & 2.00 & 2.00 & 0.38 & 3.50 & 3.50 \\
\hline $\mathrm{HC}, \mathrm{gkm}^{-1}$ & 0.80 & 0.80 & 1.14 & - & - \\
\hline $\mathrm{NO}_{\mathrm{x}}, \mathrm{gkm}^{-1}$ & 0.15 & 0.15 & 0.07 & - & - \\
\hline Data resources & \multicolumn{3}{|l|}{ This study } & \multicolumn{2}{|c|}{ (Chuang et al., 2010) } \\
\hline
\end{tabular}

${ }^{1}$ Electronic fuel injection; ${ }^{2}$ Air pollution control system; ${ }^{3}$ Non-woven fabric filter; ${ }^{4}$ Polyurethane foam filter; ${ }^{5}$ Three-way catalytic converters; ${ }^{6}$ On-board diagnostics with $\mathrm{O}_{2}$ sensor.

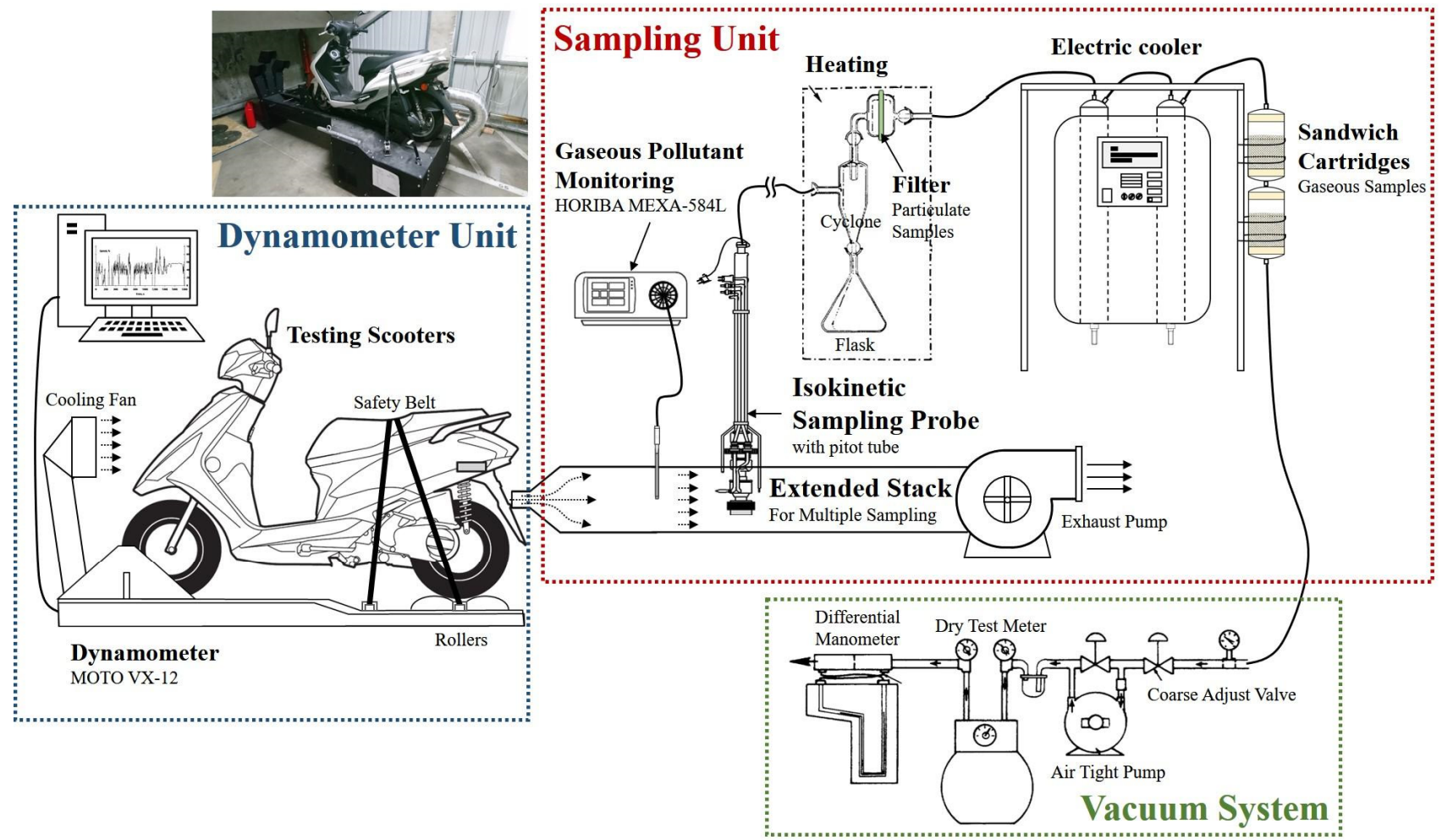

Fig. 2. Dynamometer and sampling system.

above particle collection unit was followed by an electric condenser (M\&C Tech Group gas conditioning system, PSS-5/3) to remove moisture in exhaust and simultaneously reduce the temperature to $4^{\circ} \mathrm{C}$ to inhibit the evaporation loss of semi-volatile PCDD/Fs and PCBs. A preliminary test used a three-stage glass-cartridge adsorption unit packed with 60-g XAD- $2^{\circledR}$ resin (Supelpak, Sigma-Aldrich Co., St. Louis, MO) for each cartridge to collect the gaseous PCDD/Fs and PCBs in the exhaust. Results showed that the masses of both PCDD/F and PCB congeners in the thirdstage cartridge were only contributed $0.07-1.73 \%$ of the total three-cartridge adsorption unit. Therefore, a two-stage cartridge unit was used to collect the gaseous PCDD/Fs and PCBs in this study. All samples were spiked with PCDD/F and PCB surrogate standard solutions (SS) before the sample collection. Each sample was collected isokinetically from the tested scooter-dynamometer system for 60 minutes.

After the sample was transferred to the laboratory, each of them was added with the ${ }^{13} \mathrm{C}$-labeled internal standard (IS) solution of $\mathrm{PCDD} / \mathrm{Fs}$ and $\mathrm{PCBs}$ and later extracted by a 240-mL toluene-Soxhlet extraction for 24 hours (about 6 extraction cycles per sample). The extract was concentrated 
in a vacuum concentrator and transferred to a 6-dram sample tube. There were $30 \mu \mathrm{L}$ of alternative standard (AS) solution subsequently added to the extract to estimate the recovery of analytes during the following clean-up processes. Furthermore, the sulfuric acid was added by $4 \mathrm{~mL}$ into the concentrate and well mixed by an ultrasonic homogenizer for 10 minutes. The solution was then transferred to an acid-silica-gel column and eluted with $20 \mathrm{~mL}$ of $n$-hexane. The eluent was collected, vacuum concentrated, transferred to an alumina column with $n$-hexane, and eluted by a mixture of $25-\mathrm{mL} n$-hexane and $15-\mathrm{mL}$ dichloromethane/ $n$-hexane $(4 / 96, \mathrm{v} / \mathrm{v})$. The non-planar PCBs passed through the column with the eluent as solution A. Furthermore, the alumina column was washed again with a $25-\mathrm{mL}$ solvent composed of dichloromethane $/ n$-hexane in $40 / 60, \mathrm{v} / \mathrm{v}$. The eluent was collected and concentrated to the near-dry amount, transferred to the third column packed with activated carbon/diatomaceous earth, and eluted with $5 \mathrm{~mL}$ of toluene/methanol/ethyl acetate/n-hexane $(5 / 5 / 10 / 80$, $\mathrm{v} / \mathrm{v}$ ) when the planar PCBs could be eluted out as solution B. On the other hand, the PCDD/Fs were eventually washed out by eluting $40-\mathrm{mL}$ toluene through the third packed column into solution $\mathrm{C}$. the solution $\mathrm{A}$ and $\mathrm{B}$ were then mixed and added with $15-\mu \mathrm{L}$ PCBs recovery standard (RS) solution, while the RS of PCDD/Fs was added into solution $\mathrm{C}$ before the instrumental analysis to evaluate the recovery process (EAL, 2019).

High-resolution gas chromatography coupled with highresolution mass spectrometry (HRGC/HRMS) was employed to quantify the PCDD/F and PCB compounds. The HRGC (Hewlett-Packard 6970, CA) equipped a DB-5 column (L: $60 \mathrm{~m}$, id: $0.25 \mathrm{~mm}$, film thickness: $0.25 \mu \mathrm{m}$, J\&W Scientific, CA) connected to the auto-injection port and liner. The oven temperature was set at $413 \mathrm{~K}$ for a minute and then raised to 473,503 , and $583 \mathrm{~K}$ at the rates of $30,1.5$, and $4 \mathrm{~K} \mathrm{~min}^{-1}$, respectively, and hold for 4 minutes. The column again heated to $588 \mathrm{~K}$ at a rate of $20 \mathrm{~K} \mathrm{~min}^{-1}$ and held for the last 3.5 minutes for following ionization process. The HRMS (Micromass Autospec Ultima, Manchester, UK) with a positive electron impact source was operated at $523 \mathrm{~K}$ and
$35 \mathrm{eV}$. The selected ion monitoring (SIM) mode was applied with $>10,000$ resolution power to quantify the $\mathrm{PCDD} / \mathrm{F}$ and PCB samples accurately (Lin et al., 2019a).

\section{RESULTS AND DISCUSSION}

\section{Transient Emissions of Pollutants from Scooters}

The emissions of scooters are continuous during their operation. The emission concentration (or rate) would vary with the different engine speeds, that a transient cycle test is essential to be utilized for emission inspection. Fig. 3 shows the transient averaging emission concentrations of $\mathrm{CO}, \mathrm{HC}$, and $\mathrm{NO}_{\mathrm{x}}$ from Tier 6 scooters, which has been expected to have the lowest emissions in the market so far. The idling period at the beginning of the 100-second cycle kept the CO, $\mathrm{HC}$, and $\mathrm{NO}_{\mathrm{x}}$ emission by $0.07 \%, 118$, and $47 \mathrm{ppm}$, respectively, showing the relatively low emission from the steady engine speed. This observation did not conflict with the idling emission control strategy around the world, because the idling operation provides extra emission and exposure to the scooter driver nearby. Thus, the prohibition of idling operation or auto-start-stop system design is useful for emission reduction. The production of $\mathrm{CO}$ and $\mathrm{HC}$ are generally caused by incomplete combustion with unsteady air-fuel control (Yang et al., 2007; Chiang et al., 2014), while the oxidation rate of $\mathrm{CO}$ to $\mathrm{CO}_{2}$ was sensitively affected by the local temperature in the combustion zone (Chang et al., 2014). Therefore, the CO increased with the raising engine speed, which had a higher fuel injection rate and increased the equivalent ratio $(\Phi)$ of combustion and instantly lower flame temperature. The above phenomenon could further lead to both slower the thermal breakdown of residual fuel gases in the combustion area and increase the probability of the reaction among hydrocarbon radicals to form $\mathrm{HC}$. That could be why $\mathrm{CO}$ emissions increased first and is then followed by the $\mathrm{HC}$ peak value. The $\mathrm{OBD} / \mathrm{O}_{2}$ sensor in the Tier 5 scooter could detect the abnormal $\Phi$ value and inform the next air-intake stroke (injection and airintake valve) to stabilize the combustion. On the same time,

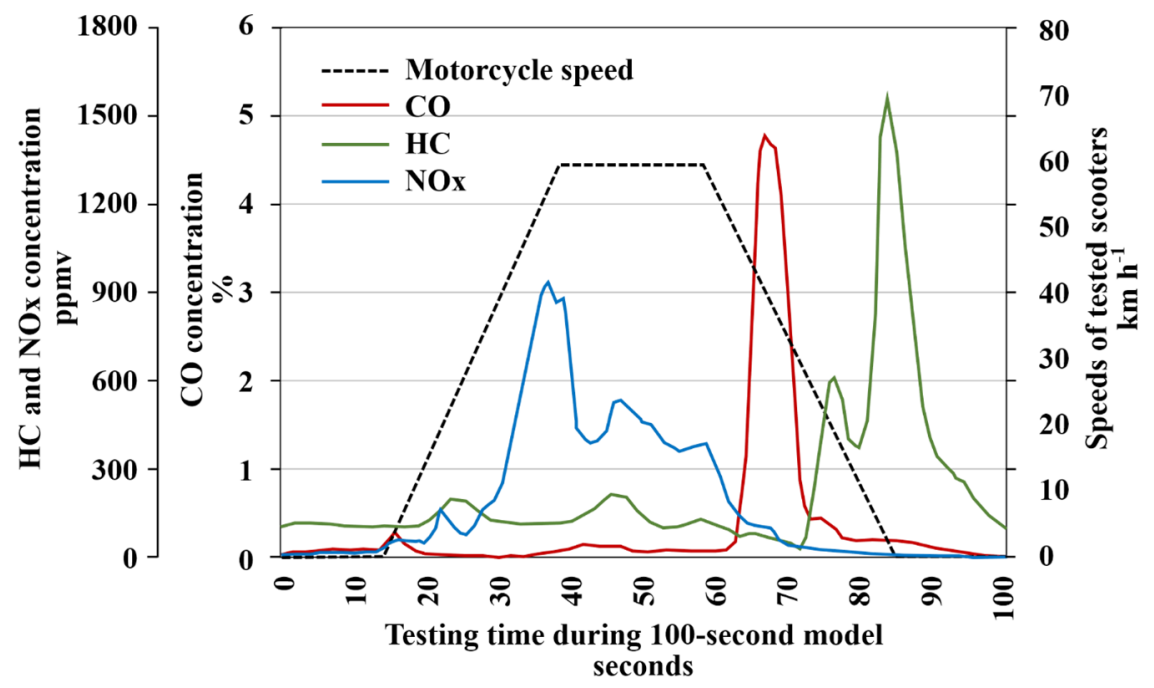

Fig. 3. Dynamic emissions of regulated gaseous pollutants along with testing cycle. 
the three-way catalytic converter (TWC) was heated up by exhaust gas to its operating temperature (generally about $300-400^{\circ} \mathrm{C}$ ), that started to convert the $\mathrm{CO}, \mathrm{HC}$, and $\mathrm{NO}_{\mathrm{x}}$ to unharmful $\mathrm{CO}_{2}, \mathrm{H}_{2} \mathrm{O}$, and $\mathrm{N}_{2}$ simultaneously (Lin et al., 2018). Therefore, the high emission concentration would not take long during the speed increasing period. Notably, the $\mathrm{CO}$ and $\mathrm{HC}$ occurred relatively high values during the slowdown period. The sudden release of the accelerator would quench the in-cylinder temperature and result for $\mathrm{CO}$ and HC productions. This period could also significantly produce PM, VOC, and SVOC, which include PCDD/Fs and PCBs.

\section{$P C D D / F$ and PCB concentrations}

The mean PCDD/F concentrations of the brand-A and brand-B scooters (Tier 5, 4-stroke; abbr. T5-4ST) were 31.7 and $25.7 \mathrm{pg} \mathrm{Nm}^{-3}$, respectively, as shown in Table 2. These PCDD/F mass emissions were $97.3-97.8 \%$ and 96.5 97.2\% lower than those from 2-stroke (avg. $1170 \mathrm{pg} \mathrm{Nm}^{-3}$ ) and 4-stroke (avg. $912 \mathrm{pg} \mathrm{Nm}^{-3}$ ) scooters fit Tier 3 in the previous study (Chuang et al., 2010). Meanwhile, the $\mathrm{PCDD} / \mathrm{F}$ toxicity emissions from T5-4ST were 2.91 and $1.86 \mathrm{pg}$ WHO-TEQ $\mathrm{Nm}^{-3}$, showing $96.0-97.4 \%$ and 94.6 $96.5 \%$ reductions from T3-2ST (72.7 WHO-TEQ $\left.\mathrm{Nm}^{-3}\right)$ and T3-4ST (53.4 WHO-TEQ $\mathrm{Nm}^{-3}$ ), respectively. More excitingly, the 4-stroke scooters approaching Tier 6 standard (T6-4ST) showed extremely lower mass and TEQ concentrations of PCDD/Fs by $6.68 \mathrm{pg} \mathrm{Nm}^{-3}$ and 0.314 pg WHO-TEQ $\mathrm{Nm}^{-3}$, respectively, which showed 99.4 and $99.3 \%$ of mass and $99.6 \%$ and $99.4 \%$ of toxicity reductions from T3-2ST and T3-4ST, respectively.

The mean PCB concentration of the tested scooters were 433 and $351 \mathrm{pg} \mathrm{Nm}^{-3}$ for brand A and B (T5-4ST), respectively, when the level of brand $\mathrm{C}$ (T6-4ST) was $118 \mathrm{pg} \mathrm{Nm}^{-3}$ (as shown in Table 3). Additionally, the corresponding mean PCBs concentrations of toxicity were $0.133-0.298$ pg WHOTEQ $\mathrm{Nm}^{-3}$ for T5-4ST and $0.0496 \mathrm{pg} \mathrm{WHO}-\mathrm{TEQ} \mathrm{Nm}^{-3}$ for T6-4ST, respectively. There is almost no report on the PCB emissions from scooters. In comparison, the emission toxicity of total PCBs were 10 times lower than those of simultaneously emitted PCDD/Fs from the testing T5-4ST and T6-4ST scooters. Moreover, the sum of $\mathrm{PCDD} / \mathrm{F}$ and PCB TEQ concentration from new generation motors were still much lower than those of older ones. However, the emissions of scooters were near to the ground surface, which could seriously increase the exposure of the residents in their daily life. The ongoing studies on air pollution in densely cities of Asian countries show that the two-wheel vehicles' emissions still dominated the contribution, even there were some prohibitions established in the metropolitan area (Yang et al., 2005; Goel and Guttikunda, 2015; Liu et al., 2017; Wu et al., 2017). Therefore, the reduction of scooter emissions, especially toxic pollutants become an important and emerging issue.

As mentioned in the previous section, the fuel feeding system of Tier 3 was significantly improved by replacing the

Table 2. PCDD/F concentrations emitted from the testing and referenced scooters.

\begin{tabular}{|c|c|c|c|c|c|c|c|c|c|}
\hline \multirow[t]{2}{*}{$\mathrm{PCDD} / \mathrm{Fs}$} & \multicolumn{2}{|c|}{$\begin{array}{c}\text { Brand A } \\
(n=4)\end{array}$} & \multicolumn{2}{|c|}{$\begin{array}{l}\text { Brand B } \\
(\mathrm{n}=3)\end{array}$} & \multicolumn{2}{|c|}{$\begin{array}{c}\text { Brand C } \\
(\mathrm{n}=3)\end{array}$} & \multirow{2}{*}{$\begin{array}{l}\text { R3-4ST } \\
(\mathrm{n}=6) \\
\text { Mean }\end{array}$} & \multirow{2}{*}{$\begin{array}{l}\text { R3-2ST } \\
(\mathrm{n}=6) \\
\text { Mean }\end{array}$} & \multirow{2}{*}{$\begin{array}{l}\mathrm{WHO}_{2005} \\
\text { TEFs }\end{array}$} \\
\hline & Mean & SD & Mean & SD & Mean & SD & & & \\
\hline 2378-TeCDD & 0.38 & 0.07 & ND & NA & ND & 1 & 6.19 & 8.30 & 1 \\
\hline 12378-PeCDD & 0.66 & 0.07 & 0.52 & 0.02 & 0.07 & 1 & 11.0 & 9.13 & 1 \\
\hline 123478-HxCDD & 0.25 & 0.01 & 0.22 & 0.01 & ND & 0.1 & 7.53 & 5.81 & 0.1 \\
\hline 123678-HxCDD & 0.68 & 0.05 & 0.37 & 0.16 & ND & 0.1 & 15.1 & 15.8 & 0.1 \\
\hline 123789-HxCDD & 0.47 & 0.03 & 0.46 & 0.17 & 0.09 & 0.1 & 12.9 & 10.8 & 0.1 \\
\hline 1234678-HpCDD & 2.41 & 0.22 & 2.82 & 0.89 & 0.80 & 0.01 & 81.7 & 115 & 0.01 \\
\hline OCDD & 6.15 & 0.44 & 4.68 & 1.00 & 2.12 & 0.003 & 326 & 446 & 0.003 \\
\hline 2378-TeCDF & 2.75 & 0.35 & 1.40 & 0.27 & 0.29 & 0.1 & 37.2 & 50.6 & 0.1 \\
\hline 12378-PeCDF & 2.41 & 0.27 & 1.49 & 0.29 & 0.53 & 0.03 & 31.7 & 39.0 & 0.03 \\
\hline 23478-PeCDF & 2.57 & 0.04 & 1.51 & 0.04 & 0.32 & 0.3 & 49.0 & 58.9 & 0.3 \\
\hline 123478-HxCDF & 1.92 & 0.26 & 1.43 & 0.40 & 0.17 & 0.1 & 31.1 & 36.5 & 0.1 \\
\hline 123678-HxCDF & 1.19 & 0.26 & 1.48 & 0.43 & 0.20 & 0.1 & 31.5 & 39.8 & 0.1 \\
\hline 123789-HxCDF & 1.83 & 0.27 & 1.71 & 0.58 & 0.26 & 0.1 & NA & 0.83 & 0.1 \\
\hline 234678-HxCDF & 0.52 & 0.05 & 0.52 & 0.08 & 0.18 & 0.1 & 31.0 & 38.2 & 0.1 \\
\hline 1234678-HpCDF & 4.08 & 0.53 & 3.70 & 1.42 & 0.49 & 0.01 & 87.0 & 91.3 & 0.01 \\
\hline 1234789-HpCDF & 0.65 & 0.05 & 0.85 & 0.33 & 0.25 & 0.01 & 16.2 & 16.6 & 0.01 \\
\hline OCDF & 2.79 & 0.09 & 2.59 & 0.90 & 0.92 & 0.003 & 137 & 187 & 0.003 \\
\hline PCDDs, pg $\mathrm{Nm}^{-3}$ & 11.0 & 0.876 & 9.07 & 2.24 & 3.07 & NA & 460 & 612 & NA \\
\hline PCDFs, pg Nm ${ }^{-3}$ & 20.7 & 2.17 & 16.7 & 4.74 & 3.61 & NA & 452 & 558 & NA \\
\hline PCDD/PCDF (mass) & 0.531 & 0.403 & 0.54 & 0.47 & 0.85 & NA & 1.02 & 1.10 & NA \\
\hline Total PCDD/Fs, pg Nm ${ }^{-3}$ & 31.7 & 3.51 & 25.8 & 7.59 & 6.68 & NA & 912 & 1170 & NA \\
\hline PCDDs, pg WHO-TEQ $\mathrm{Nm}^{-3}$ & 1.20 & 0.15 & 0.66 & 0.06 & 0.08 & NA & 22.5 & 27.3 & NA \\
\hline PCDFs, pg WHO-TEQ $\mathrm{Nm}^{-3}$ & 1.71 & 0.14 & 1.20 & 0.22 & 0.23 & NA & 30.9 & 45.4 & NA \\
\hline PCDD/PCDF (TEQ) (McKay, 2002) & 0.70 & 1.01 & 0.55 & 0.28 & 0.37 & NA & 0.73 & 0.60 & NA \\
\hline Total TEQ, pg WHO-TEQ $\mathrm{Nm}^{-3}$ & 2.91 & 0.29 & 1.86 & 0.27 & 0.31 & NA & 53.4 & 72.7 & NA \\
\hline
\end{tabular}

ND: not detected; NA: not available. 
Table 3. PCBs concentrations emitted from the testing and referenced scooters.

\begin{tabular}{|c|c|c|c|c|c|c|c|}
\hline \multirow{2}{*}{ PCBs } & \multicolumn{2}{|c|}{ Brand A $(n=4)$} & \multicolumn{2}{|c|}{ Brand B $(n=3)$} & \multicolumn{2}{|c|}{ Brand C $(n=3)$} & \multirow{2}{*}{$\mathrm{WHO}_{2005}$-TEFs } \\
\hline & Mean & SD & Mean & SD & Mean & SD & \\
\hline \multicolumn{8}{|l|}{ Non-ortho-substituted PCBs } \\
\hline 33'44'-ТeCB (PCB-77) & 38.6 & 22.1 & 31.0 & 8.64 & 9.94 & 6.82 & 0.0001 \\
\hline 344'5-ТeCB (PCB-81) & 3.30 & 20.3 & 6.11 & 7.73 & 0.984 & 1.14 & 0.0003 \\
\hline $33^{\prime} 44^{\prime} 5-\mathrm{PeCB}$ (РCB-126) & 2.45 & 3.33 & 1.09 & 1.45 & 0.396 & 0.463 & 0.1 \\
\hline 33'44'55'-НхСВ РСВ-169 & 1.23 & 2.26 & 0.309 & 0.357 & 0.184 & 0.246 & 0.03 \\
\hline \multicolumn{8}{|l|}{ Mono-ortho-substituted PCBS } \\
\hline 233'44'-РeCB (PCB-105) & 98.9 & 77.2 & 79.0 & 19.4 & 27.3 & 18.9 & 0.00003 \\
\hline 2344'5-РеCB (РCB-114) & 9.44 & 5.72 & 4.30 & 5.42 & 1.91 & 2.34 & 0.00003 \\
\hline 23'44'5-PeCB (РCB-118) & 242 & 186 & 201 & 43.5 & 68.6 & 45.2 & 0.00003 \\
\hline 2'344'5-PeCB (PCB-123) & 16.4 & 13.5 & 13.0 & 11.1 & 1.88 & 2.66 & 0.00003 \\
\hline 233'44'5-НхCВ (РCВ-156) & 11.7 & 4.59 & 8.85 & 2.38 & 3.69 & 1.88 & 0.00003 \\
\hline $233^{\prime} 44^{\prime} 5^{\prime}-\mathrm{HxCB}$ (РCB-157) & 2.49 & 0.925 & 2.13 & 0.773 & 0.784 & 0.614 & 0.00003 \\
\hline 23'44'55'-НxCB (РCB-167) & 5.31 & 2.61 & 4.31 & 1.35 & 1.72 & 0.775 & 0.00003 \\
\hline (233'44'55'-НpCB (РCB-189) & 0.893 & 0.875 & 0.633 & 0.739 & 0.285 & 0.356 & 0.00003 \\
\hline Total PCB, pgNm ${ }^{-3}$ & 433 & 294 & 352 & 72.0 & 118 & 79.4 & - \\
\hline Total TEQ, pg WHO-TEQ Nm ${ }^{-3}$ & 0.298 & 0.391 & 0.133 & 0.157 & 0.0496 & 0.0549 & - \\
\hline
\end{tabular}

carburetor with the EFI system to accurately and precisely control the fuel injection timing and mass flow before the combustion in the power stroke. The more preferable equivalent ratios between fuel and air led to more complete combustion and lower the $\mathrm{CO}, \mathrm{HC}$, prompt $\mathrm{NOx}$, as well as the $\mathrm{PCDD} / \mathrm{F}$ and $\mathrm{PCB}$ emissions in the untreated exhaust gases. Moreover, the lower entreated pollutant level could further reduce the loading of a three-way catalytic converter (TWC) to have better performances. Nevertheless, Tier 6 (brand $\mathrm{C}$ ) scooter showed an extremely low emission by equipping $\mathrm{OBD} / \mathrm{O}_{2}$ system. The frequently residual $\mathrm{O}_{2}$ information feedback from the exhaust gas could sensitively tune the EFI system, improve its performance, and reduce the PCDD/F and PCB emission. Consequently, the PCDD/Fs and PCBs could be effectively reduced with the development of scooter generations without a specific treatment design for them. However, the mechanism of PCDD/F and PCB inhibition could not be identified, since they have two major formation pathways, including (1) high-temperature oxidation and chlorination of precursors and (2) heterogeneous reaction (de novo synthesis) in the post-combustion zone (Lin et al., 2018). Therefore, an evaluation of their congener mass and TEQ distributions would be discussed in the following section.

\section{Congener Profiles of PCDD/Fs and PCBs}

The mass contributions of $\mathrm{PCDD} / \mathrm{F}$ congeners were illustrated in Fig. 4(A). The dominant congeners in brand A and B (T5-4ST) were OCDD (18.2-19.4\%), 1234678HpCDF (12.9-14.4\%), and OCDF (8.8-10.1\%), when brand C (T6-4ST) had the same top three congeners, OCDD (31.8\%), OCDF (13.8\%), and 1234678-HpCDF (7.3\%). A similar PCDD/F congener profile was observed for those of unled gasoline-fueled vehicles and diesel-fueled vehicles (U.S. EPA, 2001). Notably, the most significant change of congener profile from Tier 5 to Tier 6 scooters was the sharp increase of OCDD contributions (from 18.7 to $31.8 \%$ ), while most of the lowly chlorinated PCDFs were inhibited.
The PCDD/F congener contributions of R3-4ST and R32ST were compared with the newer generation of scooters in Fig. 4(B). Their profiles were more similar to that of T6ST. Highly chlorinated congeners, which could form by incompletely combustion of fuel, in the Tier 3 vehicles dominated the fingerprint of PCDD/Fs. This could be resulted by using carburetor as a fuel-feeding system. The carburetor is mechanically distributed the fuel by the intakeair velocity, which could not satisfy the various fuel demands from rapidly changing engine speeds. Therefore, the incompletely reacted aromatics were rapidly oxidized, chlorinated to form PCDD/Fs in high temperature (McKay, 2002; Stanmore, 2004) to form PCDDs. The mass ratios of PCDDs/PCDFs were then 1.10 and 10.2 for R3-4ST and R32ST, as well as their TEQ ratios, were 0.60 and 0.73 , respectively (as shown in Table 2). These observations supported the PCDD formation mechanism from hightemperature precursor reactions (McKay, 2002).

Fortunately, the above problem could be overcome by using the EFI system in Tier 5 vehicles, providing a more complete combustion in the power stroke. However, there were traced amounts of residual soot, catalytic metals, $\mathrm{C}_{2} \mathrm{H}_{2}$ radicals, and aromatics remained in the post-combustion area. These residues could react with each other on both the inner surface of the exhaust pipe and even in TWC to form PCDFs by de novo synthesis (Huang and Buekens, 1995; Lin et al., 2018). The latter mechanism would increase the contribution of lowly chlorinated PCDFs (4-Cl to 6-Cl substitutions) to around $39.3 \%$ in Tier 5 vehicles (as shown in Fig. 4(B)), and further affect the toxicity distribution of $\mathrm{PCDD} / \mathrm{F}$ congeners. Interestingly, Tier 6 vehicles in the current study showed a congener profile very similar to those of Tier 3 vehicles, which had 175 and 234 times higher of total mass and TEQ concentrations of $\mathrm{PCDD} / \mathrm{Fs}$, respectively. The stroke number seems no significant effect. The aforementioned $\mathrm{O}_{2}$ sensor feedback control could lead to this result in the OBD system. The TWC loading on CO, $\mathrm{HC}$, and prompt $\mathrm{NO}_{\mathrm{x}}$ treatments could be inhibited and 

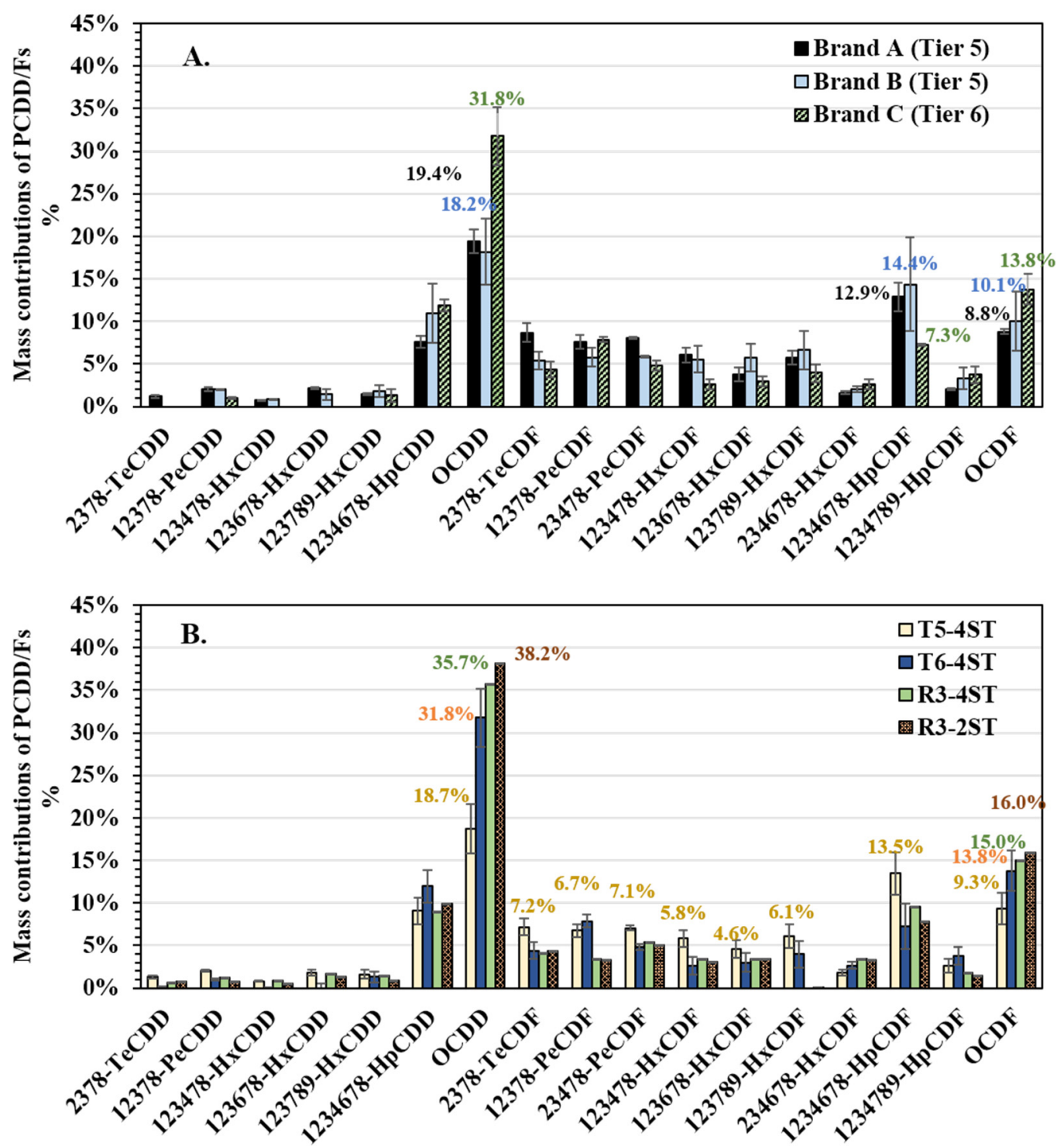

Fig. 4. Mass profiles of PCDD/F congeners from (A) three tested scooters (Tier 5 and Tier 6 ) and (B) their average compared with the 2-stroke and 4-stroke scooters (Tier 3 in reference).

released more capacity to oxidize the newly reformed PCDFs by de novo synthesis in the post-combustion zone. Therefore, the overall PCDD/F emission could be improved from Tier 5 vehicles, while the highly chlorinated PCDD/Fs predominated the congener profiles.

Fig. 5 illustrated the congener profiles of the PCB congeners. The dominant PCB congeners of Tier 5 and Tier 6 scooters were similar, when 23'44'5-PeCB (PCB-118) and 233'44'$\mathrm{PeCB}$ (PCB-105) with mono-ortho- $\mathrm{Cl}$ substitutions and 33'44'-TeCB (PCB-77) with non-ortho-Cl substitutions contributed $55.9-58.3 \%, 22.5-23.2 \%$, and $8.4-8.9 \%$ mass, respectively, of total PCBs (as shown in Fig. 5(A)). Although the most toxic non-ortho-congeners, 33'44'5-PeCB (PCB126) and $33^{\prime} 44^{\prime} 55^{\prime}-\mathrm{HxCB}$ PCB-169, had relatively low concentrations in the Tier 5 and Tier 6 vehicle emissions, the contributions of emission toxicity among PCB congeners were still dominated by them (78.9-82.1\% for PCB-126 and 6.9-12.4\% for PCB-169) (as shown in Fig. 5(B)). Fortunately, all the toxicity equivalent factors of PCBs were lower than those of $\mathrm{PCDD} / \mathrm{Fs}$ to reduce the toxicity contributions of them. However, the TEQ emissions of PCBs should be still involved in the calculation of real emission factors discussed in the following section.

\section{Effects of Tailpipe Renew on PCDD/F and PCB Emissions}

The particles from exhaust gases are very complicated, including metals, carbon, inorganic salts, acidic droplet, and various surfactants, which can inhibit the immune system of mammals (Zakharenko et al., 2017). A recent study by Emissions Database for Global Atmospheric Research (EDGAR) showed that implementing the EURO standards led to the reduction of PM emissions in internal combustion engine exhaust by $60 \%$ worldwide (Crippa et al., 2016). Therefore, the pollutants should be effectively removed before they escaped from the mobile source. The tailpipe is 

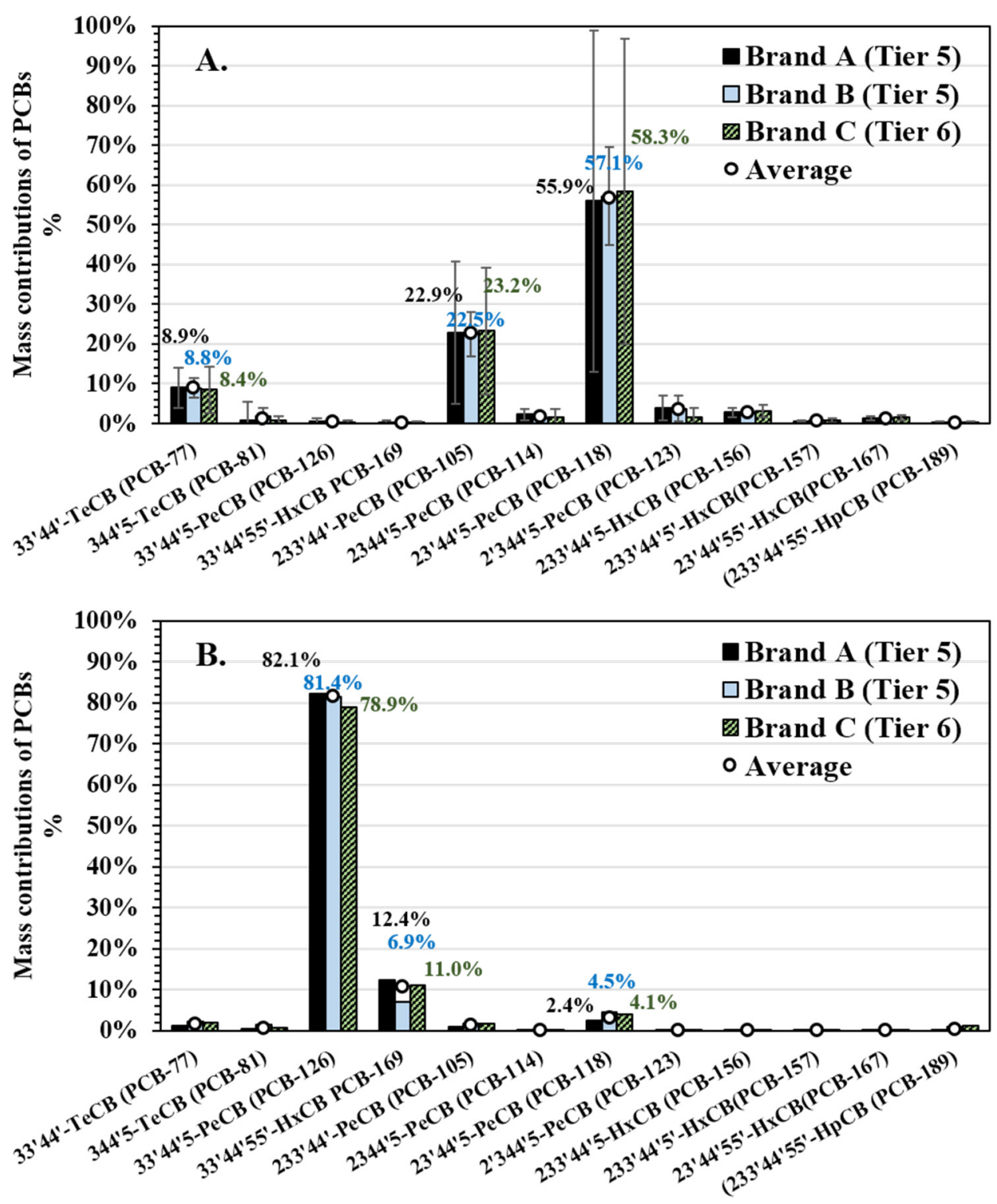

Fig. 5. (A) Mass and (B) TEQ congener profiles of PCBs in the exhausts of scooters.

the most conventional treatment technique to deal with the exhaust from scooters, when it is composed of silencer cotton, head cover, barrel body, back pressure structure, muffler cotton, tail cover, exhaust outlet, and catalyst. The particles in the exhaust might be partially trapped in the TWC converter and on the muffler cotton surface, when the exhaust gases went through the pipe. A double crisis would happen after a long-term operation of the scooters and their tailpipes. The catalytical efficiency of TWC would be inhibited by the physical and chemical poisoning, while the particles in the muffler cotton might become the carbon source for de novo synthesis to regenerate PCDD/Fs. Therefore, the exhaust pipe of the scooters was replaced and investigate the changes of the removal efficiencies on PCDD/Fs and PCBs emissions in this study.

Fig. 6 shows the changes of PCDD/F and PCB TEQ concentration by replacing three scooters with brand $\mathrm{A}$ (Tier 5), B (Tier 5), and C (Tier 6). For brand A, the PCDD/F emissions dropped $93.8 \%$ from 0.692 to $0.0431 \mathrm{pg}$ WHOTEQ $\mathrm{km}^{-1}$, when the PCBs reduced $85.3 \%$ from 0.122 to 0.0179 pg WHO-TEQ $\mathrm{km}^{-1}$ after the recent tailpipe replacement. The significant reduction could also be found in brand B (Tier 5) scooter. Its PCDD/F emission was reduced $60.0 \%$ from 0.0865 to $0.0346 \mathrm{pg}$ WHO-TEQ $\mathrm{km}^{-1}$ when PCB concentrations reduced $97.7 \%$ from 0.0021 to 0.0000479 pg WHO-TEQ $\mathrm{km}^{-1}$. However, the reductions were not observed after the tailpipe renew of brand C. The PCDD/F emissions increased from 0.0343 to $0.0668 \mathrm{pg}$ WHO-TEQ $\mathrm{km}^{-1}$, while PCBs significantly increased from 0.000511 to 0.0237 pg WHO-TEQ $\mathrm{km}^{-1}$. This abnormal phenomenon might not result from the quality of the TWC converter. It is believed that the manufacturer of brand $\mathrm{C}$ generally apply some waterproof glue and thermal insulation paint in the new tailpipe which could be released or even reacted to generate the SVOC by the hot exhaust gases passed through. Consequently, the tailpipe renew could effectively reduce 

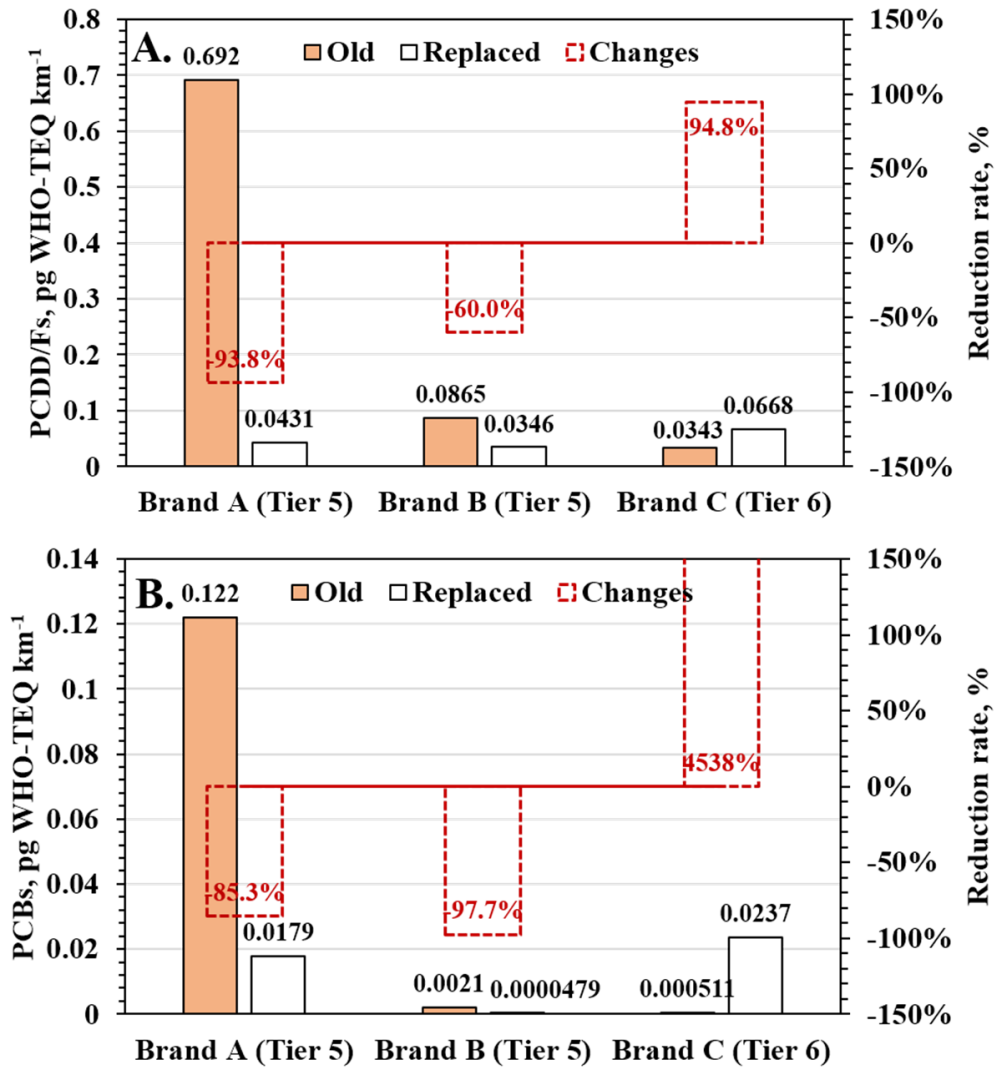

Fig. 6. Changes of (A) PCDD/F and (B) PCB emissions from scooters after the replacement of tailpipes.

the $\mathrm{PCDD} / \mathrm{F}$ and $\mathrm{PCB}$ concentration in the exhaust, when several cases would still have a delay to perform enough removal efficiencies after a period of operation.

\section{Emission Factors and Annual Emission Reduction}

Emission factors (EFs) are normalized indexes for comparing the vehicles with various conditions, mileage, emission control equipment, feeding fuels etc. in the same base, while most of the emission standards refer to them. Table 4 showed the EFs of regulated pollutants, while the $\mathrm{CO}$ and $\mathrm{NO}_{\mathrm{x}}$ emissions still excesses the limits of Tier 5 and Tier 6 standards in several cases. The trade-off between $\mathrm{CO}$ and $\mathrm{NO}_{\mathrm{x}}$ emissions is always a dilemma, when the vehicle emission standards are getting stricter worldwide. The wellcontrolled combustion by OBD and high-quality TWC converter would be the essential solution for a new generation of scooters.

On the other hand, the EFs of total PCDD/Fs $\left(\mathrm{EF}_{\mathrm{PCDD} / \mathrm{Fs}}\right)$ of the R3-4ST and R3-2ST were 81.0 and $96.6 \mathrm{pg}$ WHOTEQ $\mathrm{km}^{-1}$, respectively, as shown in Table 4 (Chuang et al., 2010). The piston operation design in strokes led to different $\mathrm{EF}_{\mathrm{PCDD} / \mathrm{Fs}}$. The 2-stroke engines had 19.3\% higher $\mathrm{EF}_{\mathrm{PCDD} / \mathrm{Fs}}$ than those of the 4-stroke ones, when PCDD/F concentration of R3-2ST showed $36.1 \%$ higher value than R3-4ST in tailpipe. Two-stroke scooter was one of the major sources of air pollution in many cities (Platt et al., 2014), while there are scientific suggestions that scooters will emit more PAHs than all other vehicles combined in Europe by 2020 (Geivanidis et al., 2008). Our finding indicated that the 4- stroke engine with separate intake and exhaust stroke could improve the combustion, decreased the incomplete oxidation of fuel, and eventually reduced the $\mathrm{PCDD} / \mathrm{F}$ formation. The $\mathrm{EF}_{\mathrm{PCDD} / \mathrm{Fs}}$ of T5-4ST were 1.18-1.21 pg WHO-TEQ $\mathrm{km}^{-1}$, representing $98.7 \%$ reduction from $\mathrm{R} 3-2 \mathrm{ST}$ scooters. The $\mathrm{EF}_{\mathrm{PCDD} / \mathrm{Fs}}$ of T6-4ST was lower by $0.0715 \mathrm{pg}$ WHO-TEQ $\mathrm{km}^{-1}$, representing $99.9 \%$ reductions from R3-2ST scooters. By adding the EFs of PCBs $\left(\mathrm{EF}_{\mathrm{PCBs}}\right)$ into total TEQ emission $\left(\mathrm{EF}_{\text {total }}=\mathrm{EF}_{\mathrm{PCDD} / \mathrm{Fs}}+\mathrm{EF}_{\mathrm{PCBs}}\right)$, the $\mathrm{EF}_{\text {total }}$ of T5-4ST and T64ST became 1.30-1.34 and 0.0715 pg WHO-TEQ $\mathrm{km}^{-1}$, respectively, which were still extremely lower than those from Tier 3 vehicles. That is to say, the improvement of fuelfeeding and OBE systems could not only reduce the regulated pollutants $\left(\mathrm{CO}, \mathrm{HC}\right.$, and $\left.\mathrm{NO}_{\mathrm{x}}\right)$ but also could effectively reduce the $\mathrm{PCDD} / \mathrm{Fs}$ emission (Yang et al., 2005). The correlation between the emission factors of PCDD/Fs (or $\mathrm{PCBs})$ and regulated pollutants $\left(\mathrm{CO}, \mathrm{HC}\right.$, and $\left.\mathrm{NO}_{\mathrm{x}}\right)$ were not found, even the combustion condition would affect all of them simultaneously. This could result from the effective operation of the air pollution control system of the scooter.

This study estimated the annual reduction of the total PCDD/F TEQ emissions according to the following equation.

$E_{P C D D / F-T E Q}=\sum_{1}^{n} N_{i} \times E F_{i} \times V K T_{i}$

where $E_{P C D D / F-T E Q}$ is the annual TEQ emissions of PCDD/Fs; $N_{i}, E F_{i}$, and $\mathrm{VKT}_{\mathrm{i}}$ represent the amount, TEQ emission 


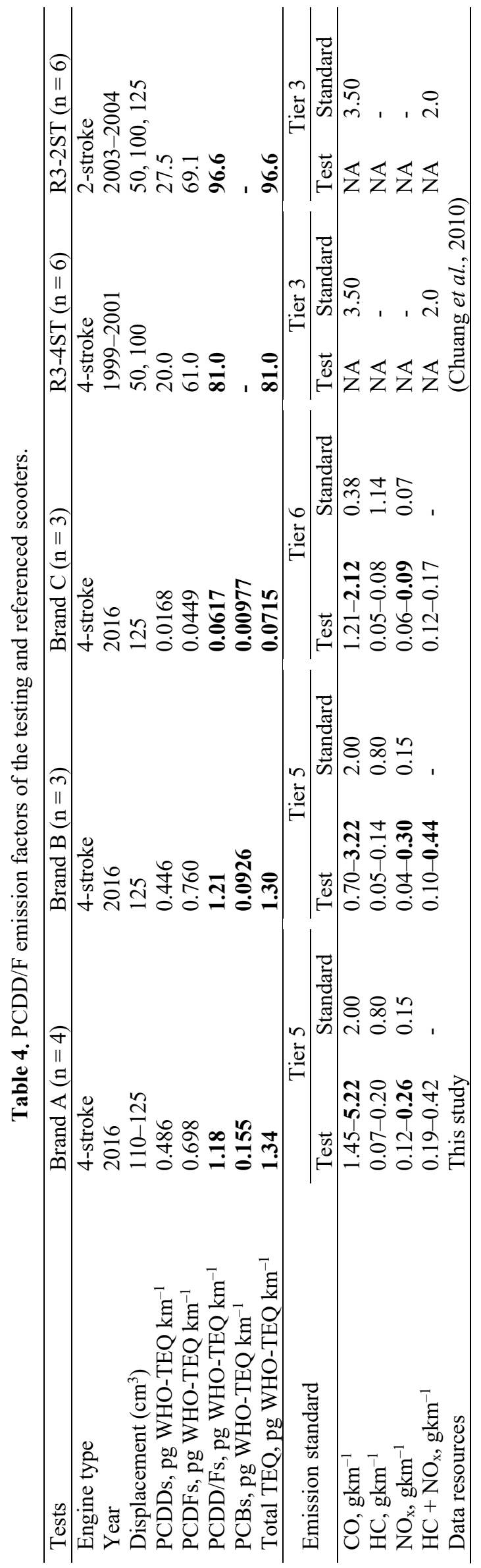

factors and the average vehicle kilometers traveled (VKT) of the scooter fit the specific Tier $1 / 2 / 3 / 4 / 5 / 6$ standards in Taiwan. In 2019, the amounts of Tier $1+2$, Tier 3 , Tier 4 , Tier 5, Tier 6-scooters were 1,279,389, 1,787,666, 1,741,999, $6,539,232$, and 2,644,636 vehicles, respectively (as shown in Fig. 1). Since there is still very limit of international research on the PCDD/F and PCB emissions from scooters, the $\mathrm{EFs}$ of $\mathrm{PCDD} / \mathrm{F}$ were then classified into only three groups in the current study. The first group used $\mathrm{EF}_{\mathrm{R} 3-4 \mathrm{ST}}$ (81.0 pg WHO-TEQ km $\mathrm{km}^{-1}$ ), standing for the Tier $1-4$ scooter emissions, when the other two used $\mathrm{EF}_{\mathrm{T} 5-4 \mathrm{ST}}$ (1.195 pg WHO-TEQ km ${ }^{-1}$ ) and EF T6-4ST $_{\text {(0.0617pg WHO-TEQ km }}{ }^{-1}$ ) to represent the Tier 5 and 6 emissions, respectively. The VKT of scooters reported by Taiwan Emission Database System 10.0 (TEDS 10.0) were about 3,471 to $5,070 \mathrm{~km} \mathrm{yr}^{-1}$ in each administrative region. We selected an averaged VKT as 4,108 $\mathrm{km} \mathrm{yr}^{-1}$ (as shown in Table 5) for further calculation (TWEPA, 2019). Finally, the original annual TEQ emissions in 2019 is then evaluated as $1.63 \mathrm{~g}$ WHO-TEQ, contributing only less than $2 \%$ of total annual PCDD/F TEQ emission in Taiwan. However, the scooter emission is much closer to the human life and exposure than those highly contributively stationary sources. Therefore, the annual emissions that replacing all scooters by Tier 6 levels was then estimated based on 2019 statistics. The improved annual emission became only $3.55 \mathrm{mg}$ ( $>99.7 \%$ reduction). This significant drop points out that the ongoing new emission standards for scooters could not only solve the problem of fine particle and regulated pollutant emissions but the potential risks from PCDD/F and PCB emissions around us, especially in the metropolitan area.

\section{CONCLUSIONS}

There were seven Tier 5 and three Tier 6 scooters tested with a 100 -second transient model to analyze the PCDD/F and PCB emission and compare with those from the Tier 3 motors reported in the previous study. There are several important findings as follows.

1. PCDD/F toxicity emissions from Tier 5 and 6 scooters were 1.86-2.91 and 0.314 pg WHO-TEQ $\mathrm{Nm}^{-3}$, representing 94.6-97.4\% and $99.4-99.6 \%$ reductions from those of Tier 3 motors. Meanwhile, the toxicity emissions of PCBs

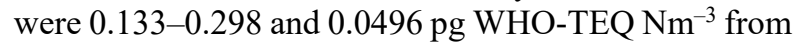
Tier 5 and Tier 6 scooters, respectively, which were 10 times lower than those of PCDD/Fs.

2. PCDD/F were dominated by OCDD, 1234678-HpCDF, and OCDF from Tier 3 scooters, which were contained in the incompletely combusted soot and hydrocarbons. Lowly chlorinated PCDFs more contributed to Tier 5 emission, indicating the occurrence of de novo synthesis, when it could be inhibited by equipping OBD system in Tier 6. The PCB congeners were predominated by mono-ortho-PCB-118 and -105 and non-ortho-PCB-77 with from both Tier 5 and 6 scooters.

3. The improvement of EFI and OBD systems from a carburetor without feedback control not only reduced the regulated pollutants but also effectively reduces PCDD/F emissions. 
Table 5. Estimation of annual PCDD/F TEQ emissions from scooters in both original and improved cases.

\begin{tabular}{llllllll}
\hline \multirow{2}{*}{ Scooter Gen. } & \multirow{2}{*}{ VKT } & \multirow{2}{*}{ EF } & \multicolumn{2}{c}{ Original } & & \multicolumn{2}{c}{ Improved } \\
\cline { 4 - 5 } & & & Num. vehicle & Emission, $\mathrm{g}$ & & Num. vehicle & Emission, mg \\
\hline Tier 1-4 & 4108 & 81 & $4,809,054$ & 1.60 & 0 & 0 \\
Tier 5 & 4108 & 1.195 & $6,539,232$ & 0.0321 & 0 & 0 \\
Tier 6 & 4108 & 0.0617 & $2,644,636$ & 0.000670 & & $13,992,922$ & 3.55 \\
Annual Emission & & & & $1.63 \mathrm{~g} \mathrm{yr}^{-1}$ & & $3.55 \mathrm{mg} \mathrm{yr}^{-1}$ \\
\hline
\end{tabular}

4. The tailpipe renew could effectively reduce $60.0-93.8 \%$ of $\mathrm{PCDD} / \mathrm{F}$ and $85.3-97.7 \%$ of $\mathrm{PCB}$ concentrations in the exhaust, when several cases would still have a delay to perform enough removal efficiencies after a period of operation.

5. The annual TEQ emissions in 2019 is evaluated as $1.63 \mathrm{~g}$ WHO-TEQ and could be improved to $3.55 \mathrm{mg}(>99.7 \%$ reduction) by replacing all scooters by Tier 6 levels.

This is the first study that points out the emissions of PCDD/Fs and PCBs from scooters could be effectively reduced along with the regulated pollutants $(\mathrm{CO}, \mathrm{HC}$, and $\mathrm{NO}_{\mathrm{x}}$ ) by improving the fuel feeding and on-board diagnostic system. Furthermore, the exposure and health risk of human near the scooter emission could decrease in the urban area when the next generation of scooter comes.

\section{ACKNOWLEDGEMENT}

The authors really appreciate the funding provided by a research project (MOST 107-EPA-F-019-001) from Environmental Protection Administration in Taiwan, R.O.C. The technical supports by Super Micro Mass research and Technology Center of Cheng Shiu University in Taiwan, the professional consultation from Professor Li-Hao Young, and Mr. Ying-Shun Chang are really appreciated.

\section{SUPPLEMENTARY MATERIAL}

Supplementary data associated with this article can be found in the online version at http://www.aaqr.org.

\section{REFERENCES}

Alves, C.A., Barbosa, C., Rocha, S., Calvo, A., Nunes, T., Cerqueira, M., Pio, C., Karanasiou, A. and Querol, X. (2015). Elements and polycyclic aromatic hydrocarbons in exhaust particles emitted by light-duty vehicles. Environ. Sci. Pollut. Res. 22: 11526-11542. https://doi.org /10.1007/s11356-015-4394-x

Bawden, K., Ormerod, R., Starke, G. and Zeise, K. (2004). Inventory of dioxin emissions in Australia. National Dioxins Program Technical Report 3, Department of the Environment and Heritage, Australian Government.

Booth, S., Hui, J., Alojado, Z., Lam, V., Cheung, W., Zeller, D., Steyn, D. and Pauly, D. (2013). Mar. Pollut. Bull. 75: 182-186. https://doi.org/10.1016/j.marpolbul.2013.07.041

Brož, J., Grabic, R., Kilián, J., Lojkásek, M., Marklund, S., Ocelka, T., Pekárek, V., Přibyl, J., Tydlitát, V. and Výška, J. (2000). The effect of oils on PAH, PCDD, PCDF, and
PCB emissions from a spark engine fueled with leaded gasoline. Chemosphere 41: 1905-1911. https://doi.org/10. 1016/S0045-6535(00)00053-9

Chang, Y.C., Lee, W.J., Wang, L.C., Yang, H.H., Cheng, M.T., Lu, J.H., Tsai, Y.I. and Young, L.H. (2014). Effects of waste cooking oil-based biodiesel on the toxic organic pollutant emissions from a diesel engine. Appl. Energy 113: 631-638. https://doi.org/10.1016/j.apenergy.2013.0 8.005

Chen, P., Kang, S., Li, C., Li, Q., Yan, F., Guo, J., Ji, Z., Zhang, Q., Hu, Z., Tripathee, L. and Sillanpää, M. (2018). Source apportionment and risk assessment of atmospheric polycyclic aromatic hydrocarbons in Lhasa, Tibet, China. Aerosol Air Qual. Res. 18: 1294-1304. https://doi.org/10. 4209/aaqr.2017.12.0603

Cheng, N., Li, Y., Sun, F., Chen, C., Wang, B., Li, Q., Wei, P., and Cheng, B. (2017). Ground-level $\mathrm{NO}_{2}$ in urban Beijing: Trends, distribution, and effects of emission reduction measures. Aerosol Air Qual. Res. 18: 343-356. https://doi.org/10.4209/aaqr.2017.02.0092

Chernyshev, V.V., Zakharenko, A.M., Ugay, S.M., Hien, T.T., Hai, L.H., Kholodov, A.S., Burykina, T.I., Stratidakis, A.K., Mezhuev, Ya.O., Tsatsakis, A.M. and Golokhvast, K.S. (2018). Morphologic and chemical composition of particulate matter in motorcycle engine exhaust. Toxicol. Rep. 5: 224-230. https://doi.org/10.1016/j.toxrep.2018.0 1.003

Chiang, H.L., Huang, P.H., Lai, Y.M. and Lee, T.Y. (2014). Comparison of the regulated air pollutant emission characteristics of real-world driving cycle and ECE cycle for scooters. Atmos. Environ. 87: 1-9. https://doi.org/10.1 016/j.atmosenv.2013.12.031

Chuang, S.C., Chen, S.J., Huang, K.L., Chang-Chien, G.P., Wang, L.C. and Huang, Y.C. (2010). Emissions of polychlorinated dibenzo-p-dioxin and polychlorinated dibenzofuran from motorcycles. Aerosol Air Qual. Res. 10: 533-539. https://doi.org/10.4209/aaqr.2010.04.0029

Corsolini, S., Ademollo, N., Martellini, T., Randazzo, D., Vacchi, M. and Cincinelli, A. (2017). Legacy persistent organic pollutants including PBDEs in the trophic web of the Ross Sea (Antarctica). Chemosphere 185: 699-708. https://doi.org/10.1016/j.chemosphere.2017.07.054

Costagliola, M.A., Murena, F. and Prati, M.V. (2014). Exhaust emissions of volatile organic compounds of powered two-wheelers: Effect of cold start and vehicle speed. Contribution to greenhouse effect and tropospheric ozone formation. Sci. Total Environ. 468: 1043-1049. https://doi.org/10.1016/j.scitotenv.2013.09.025

Costagliola, M.A., Prati, M.V. and Murena, F. (2016). 
Bioethanol/gasoline blends for fuelling conventional and hybrid scooter. Regulated and unregulated exhaust emissions. Atmos. Environ. 132: 133-140. https://doi.org/ 10.1016/j.atmosenv.2016.02.045

Crippa, M., Janssens-Maenhout, G., Guizzardi, D. and Galmarini, S. (2016). EU effect: Exporting emission standards for vehicles through the global market economy. J. Environ. Manage. 183: 959-971. https://doi.org/10.1016 /j.jenvman.2016.09.068

DeMarini, D.M., Brooks, L.R., Warren, S.H., Kobayashi, T., Gilmour, M.I. and Singh, P. (2004). Bioassay-directed fractionation and Salmonella mutagenicity of automobile and forklift diesel exhaust particles. Environ. Health Perspect. 112: 814-819. https://doi.org/10.1289/ehp.6578

Dhital, N.B., Yang, H.H., Wang, L.C., Hsu, Y.T., Zhang, H.Y., Young, L.H. and Lu, J.H. (2019). VOCs emission characteristics in scooter exhaust with different emission control devices. Atmos. Pollut. Res. 10: 1498-1506. https://doi.org/10.1016/j.apr.2019.04.007

Durant, J.L., Busby, W.F., Lafleur, A.L., Penman, B.W. and Crespi, C.L. (1996). Human cell mutagenicity of oxygenated, nitrated and unsubstituted polycyclic aromatic hydrocarbons associated with urban aerosols. Mutat. Res. Genet. Toxicol. 371: 123-157. https://doi.org/10.1016/S 0165-1218(96)90103-2

Durant, J.L., Lafleur, A.L., Busby, W.F., Donhoffner, L.L., Penman, B.W. and Crespi, C.L. (1999). Mutagenicity of $\mathrm{C}_{24} \mathrm{H}_{14} \mathrm{PAH}$ in human cells expressing CYP1A1. Mutat. Res. Genet. Toxicol. Environ. Mutagen. 446: 1-14. https://doi.org/10.1016/S1383-5718(99)00135-7

Environmental Protection Administration (EAL) (2019). NIEA method A808.75B. Environmental Protection Administration, Execusive Yuan, Taiwan R.O.C.

Flesch-Janys, D. (1996). Elimination of polychlorinated dibenzo- $p$-dioxins and dibenzofurans in occupationally exposed persons. J. Toxicol. Environ. Health 47: 363378. https://doi.org/10.1080/009841096161708

Gao, Q., Ben, Y.J., Dong, Z.M. and Hu, J.Y. (2019). Agedependent human elimination half-lives of dioxin-like polychlorinated biphenyls derived from biomonitoring data in the general population. Chemosphere 222: 541548. https://doi.org/10.1016/j.chemosphere.2019.01.168

Geivanidis, S., Ntziachristos, L., Samaras, Z., Xanthopoulos, A., Steven, H. and Bugsel, B. (2008). Study on possible new measures concerning scooter emissions. European Commission. https://ec.europa.eu/growth/content/studypossible-new-measures-concerning-motorcycle-emissions$0 \_$en

Goel, R. and Guttikunda, S.K. (2015). Evolution of on-road vehicle exhaust emissions in Delhi. Atmos. Environ. 105: 78-90. https://doi.org/10.1016/j.atmosenv.2015.01.045

Grana, M., Toschi, N., Vicentini, L., Pietroiusti, A. and Magrini, A. (2017). Exposure to ultrafine particles in different transport modes in the city of Rome. Environ. Pollut. 228: 201-210. https://doi.org/10.1016/j.envpol.20 17.05.032

Grivas, G., Cheristanidis, S., Chaloulakou, A., Koutrakis, P. and Mihalopoulos, N. (2018). Elemental composition and source apportionment of fine and coarse particles at traffic and urban background locations in Athens, Greece. Aerosol Air Qual. Res. 18: 1642-1659. https://doi.org/10. 4209/aaqr.2017.12.0567

Hu, H., Xu, J.G., Shen, Q., Shi, F. and Chen, Y.J. (2018). Travel mode choices in small cities of China: A case study of Changting. Transp. Res. D 59: 361-374. https://doi.org /10.1016/j.trd.2018.01.013

Huang, H. and Buekens, A. (1995). On the mechanisms of dioxin formation in combustion processes. Chemosphere 31: 4099-4117. https://doi.org/10.1016/0045-6535(95)80 $011-9$

International Agency for Research on Cancer (IARC) (1997). Polychlorinated dibenzo-para-dioxins and polychlorinated dibenzofurans. IARC Monographs on the Evaluation of Carcinogenic Risks to Humans Volume 69, World Health Organizatio https://publications.iarc.fr/87

International Agency for Research on Cancer (IARC) (2016). Polychlorinated biphenyls and polybrominated biphenyls. IARC Monographs on the Evaluation of Carcinogenic Risks to Humans Volume 107, World Health Organization. https://publications.iarc.fr/Book-AndReport-Series/Iarc-Monographs-On-The-IdentificationOf-Carcinogenic-Hazards-To-Humans/PolychlorinatedBiphenyls-And-Polybrominated-Biphenyls-2015

Iwata, H., Watanabe, M., Okajima, Y., Tanabe, S., Amano, M., Miyazaki, N., and Petrov, E.A. (2004). Toxicokinetics of PCDD, PCDF, and coplanar PCB congeners in Baikal seals, Pusa sibirica: Age-related accumulation, maternal transfer, and hepatic sequestration. Environ. Sci. Technol. 38: 3505-3513. https://doi.org/10.1021/es035461+

Jang, E., Jeong, T., Yoon, N. and Jeong, S. (2020). Source apportionment of airborne PCDD/F at industrial and urban sites in Busan, South Korea. Chemosphere 239: 124717. https://doi.org/10.1016/j.chemosphere.2019.124717

Li, M.H. and Hansen, L.G. (1996). Enzyme induction and acute endocrine effects in prepubertal female rats receiving environmental PCB/PCDF/PCDD mixtures. Environ. Health Perspect. 104: 712-722. https://doi.org/10.1289/ ehp.96104712

Lin, S.L., Aniza, R., Lee, Y.Y. and Wang, C.L. (2018). Reduction of traditional pollutants and polychlorinated dibenzo- $p$-dioxins and dibenzofurans emitted from a diesel engine generator equipped with a catalytic ceramic fiber filter system. Clean Technol. Environ. Policy 20: 1297-309. https://doi.org/10.1007/s10098-018-1559-6

Lin, S.L., Lee, K.L., Wu, J.L. and Cheruiyot, N.K. (2019a). Effects of a quenching treatment on $\mathrm{PCDD} / \mathrm{F}$ reduction in the bottom ash of a lab waste incinerator to save the energy and cost incurred from post-thermal treatment. Waste Manage. 95: 316-24. https://doi.org/10.1016/j.was man.2019.06.024

Lin, Y.C., Li, Y.C., Amesho, K.T.T., Chou, F.C. and Cheng, P.C. (2019b). Characterization and quantification of $\mathrm{PM}_{2.5}$ emissions and $\mathrm{PAHs}$ concentration in $\mathrm{PM}_{2.5}$ from the exhausts of diesel vehicles with various accumulated mileages. Sci. Total Environ. 660: 188-198. https://doi.org/10.1016/j.scitotenv.2019.01.007

Liu, Y., Song, M., Liu, X., Zhang, Y., Hui, L., Kong, L., Zhang, Y., Zhang, C., Qu, Y., An, J., Ma, D., Tan, Q. and 
Feng, M. (2020). Characterization and sources of volatile organic compounds (VOCs) and their related changes during ozone pollution days in 2016 in Beijing, China. Environ. Pollut. 257: 113599. https://doi.org/10.1016/j.e nvpol.2019.113599

Liu, Y.H., Liao, W.Y., Li, L., Huang, Y.T. and Xu, W.J. (2017). Vehicle emission trends in China's Guangdong Province from 1994 to 2014. Sci. Total Environ. 586: 512-521. https://doi.org/10.1016/j.scitotenv.2017.01.215

Lohmann, R., Breivik, K., Dachs, J. and Muir, D. (2007). Global fate of POPs: Current and future research directions. Environ. Pollut. 150: 150-165. https://doi.org/ 10.1016/j.envpol.2007.06.051

Macedo, V.C., Daemme, L.C., Penteado, R., da Motta, H.N. and Correa, S.M. (2017). BTEX emissions from flex fuel scooters. Atmos. Pollut. Res. 8: 1160-1169. https://doi.org/ 10.1016/j.apr.2017.05.006

Manibusan, S. and Mainelis, G. (2020). Performance of four consumer-grade air pollution measurement devices in different residences. Aerosol Air Qual. Res. 20: 217-230. https://doi.org/10.4209/aaqr.2019.01.0045

McKay, G. (2002). Dioxin characterisation, formation and minimisation during municipal solid waste (MSW) incineration: Review. Chem. Eng. J. 86: 343-68. https://doi.org/10.1016/S1385-8947(01)00228-5

Oehme, M., Larssen, S. and Brevik, E.M. (1991). Emission factors of PCDD and PCDF for road vehicles obtained by tunnel experiment. Chemosphere 23: 1699-1708. https://doi.org/10.1016/0045-6535(91)90018-9

Park, H.S., Kim, R.E., Park, Y.M., Hwang, K.C., Lee, S.H., Kim, J.J., Choi, J.Y., Lee, D.G., Chang, L.S. and Choi, W. (2020). The potential of commercial sensors for spatially dense short-term air quality monitoring based on multiple short-term evaluations of 30 sensor nodes in urban areas in Korea. Aerosol Air Qual. Res. 20: 369-380. https://doi.org/10.4209/aaqr.2019.03.0143

Pirkle, J.L., Wolfe, W.H., Patterson, D.G., Needham, L.L., Michalek, J.E., Miner, J.C., Peterson, M.R., and Phillips, D.L. (1989). Estimates of the half-life of 2,3,7,8tetrachlorodibenzo- $p$-dioxin in Vietnam veterans of operation ranch hand. J. Toxicol. Environ. Health 27: 165-171. https://doi.org/10.1080/15287398909531288

Platt, S.M., Haddad, I.E., Pieber, S.M., Huang, R.J., Zardini, A.A., Clairotte, M., Suarez-Bertoa, R., Barmet, P., Pfaffenberger, L., Wolf, R., Slowik, J.G., Fuller, S.J., Kalberer, M., Chirico, R., Dommen, J., Astorga, C., Zimmermann, R., Marchand, N., Hellebust, S., TemimeRoussel, B., Baltensperger, U., and Prévôt, A.S.H. Twostroke scooters are a dominant source of air pollution in many cities. Nat. Commun. 5: 3749. https://doi.org/10.10 38/ncomms4749

Prati, M.V., Zamboni, G., Costagliola, M.A., Meccariello, G., Carraro, C. and Capobianco, M. (2011). Influence of driving cycles on Euro 3 scooter emissions and fuel consumption. Energy Convers. Manage. 52: 3327-3336. https://doi.org/10.1016/j.enconman.2011.06.004

Quass, U., Fermann, M. and Broker, G. (2004). The European dioxin air emission inventory project - Final results. Chemosphere 54: 1319-1327. https://doi.org/10.1
016/S0045-6535(03)00251-0

Que, D.E., Chao, H.R., Hsu, Y.C., Cui, K., Chen, S., Tayo, L.L., Arcega, R.D., Tsai, Y.I., Lu, I.C., Wang, L.C., Young, L.H., Yu, K.L.J., Lai, C.Y., Hou, W.C. and Lin, S.L. (2019). Emission of carbonyl compounds from cooking oil fumes in the night market areas. Aerosol Air Qual. Res. 19: 1566-1578. https://doi.org/10.4209/aaqr. 2019.06.0289

Sinkkonen, S. and Paasivirta, J. (2000). Degradation halflife times of PCDDs, PCDFs and PCBs for environmental fate modeling. Chemosphere 40: 943-949. https://doi.org/ 10.1016/S0045-6535(99)00337-9

Ssebugere, P., Sillanpaa, M., Matovu, H. and Mubiru, E. (2019). Human and environmental exposure to PCDD/Fs and dioxin-like PCBs in Africa: A review. Chemosphere 223: 483-493. https://doi.org/10.1016/j.chemosphere.201 9.02 .065

Stanmore, B.R. (2004). The formation of dioxins in combustion systems. Combust. Flame 136: 398-427. https://doi.org/10.1016/j.combustflame.2003.11.004

Tsai, J.H., Huang, P.H. and Chiang, H.L. (2017). Air pollutants and toxic emissions of various mileage scooters for ECE driving cycles. Atmos. Environ. 153: 126-134. https://doi.org/10.1016/j.atmosenv.2013.12.031

Tsai, J.H., Lin, S.L., Chen, S.J., Guo, C.J., Huang, K.L., Lee, J.T., Yeh, K.J.C., Chiu, J.Y. and Lin, C.C. (2018a). Emission characteristics of particulate matter and particle-bound metals from a diesel engine generator fueled with waste cooking oil-based biodiesel blended with $n$-butanol and acetone. Aerosol Air Qual. Res. 18: 1246-1254. https://doi.org/10.4209/aaqr.2018.03.0090

Tsai, J.H., Yao, Y.C., Huang, P.H. and Chiang, H.L. (2018b). Fuel economy and volatile organic compound exhaust emission for scooters with various running mileages. Aerosol Air Qual. Res. 18: 3056-3067. https://doi.org/10.4209/aaqr.2018.07.0264

Tsai, J.H., Gu, W.T., Chung, I.I. and Chiang, H.L. (2019a). Airborne air toxics characteristics and inhalation health risk assessment of a metropolitan industrial complex. Aerosol Air Qual. Res. 19: 2477-2489. https://doi.org/10. 4209/aaqr.2019.08.0422

Tsai, J.H., Ko, Y.L., Huang, C.M. and Chiang, H.L. (2019b). Effects of blending ethanol with gasoline on the performance of scooter catalysts and airborne pollutant emissions. Aerosol Air Qual. Res. 19: 2781-2792. https://doi.org/10.4209/aaqr.2019.10.0539

Tsai, J.H., Chen, Y.R., Chen, S.J., Lin, S.L., Huang, K.L., Lin, C.C. and Chiu, J.Y. (2020). Characteristics of emissions from a portable two-stroke gasoline engine. Aerosol Air Qual. Res. 20: 630-642. https://doi.org/10.4209 /aaqr.2019.12.0650

Tu, CM. (2018). 2018 counselling and management of $P C D D / F, P M_{2.5}$, and hazardouos air pollutant emission sources and supporting the survey of environmental incidents. Environmental Protection Bureau, Taoyuan City, Taiwan.

TWEPA (2019). Taiwan Emission database system 10.0. Environmental Protection Administration Executive Yuan, R.O.C. (Taiwan). 
TWEPA (2020). Environment resource database. Environmental Protection Administration Executive Yuan, R.O.C. (Taiwan).

U.S. EPA (2001). Database of sources of environmental releases of dioxin like compounds in the United States. United States Environmental Protection Agency.

Vecchiato, M., Argiriadis, E., Zambon, S., Barbante, C., Toscano, G., Gambaro, A., and Piazza, R. (2015). (2015). Persistent Organic Pollutants (POPs) in Antarctica: Occurrence in continental and coastal surface snow. Microchem. J. 119: 75-82. https://doi.org/10.1016/j.micr oc. 2014.10 .010

Wang, B., Huang, J., Deng, S.B., Yang, X.L. and Yu, G. (2012). Addressing the environmental risk of persistent organic pollutants in China. Front. Environ. Sci. Eng. 6: 2-16. https://doi.org/10.1007/s11783-011-0370-y

Wheatley, A. and Sadhra, S. (2010). Carcinogenic risk assessment for emissions from clinical waste incineration and road traffic. Int. J. Environ. Health Res. 20: 313-327. https://doi.org/10.1080/09603121003663487

Wu, R.R., Zhao, Y., Zhang, J. and Zhang, L. (2020). Variability and sources of ambient volatile organic compounds based on online measurements in a suburban region of Nanjing, Eastern China. Aerosol Air Qual. Res. 20: 606-619. https://doi.org/10.4209/aaqr.2019.10.0517

Wu, Y., Zhang, S., Hao, J., Liu, H., Wu, X., Hu, J., Walsh, M.P., Wallington, T.J., Zhang, K.M., and Stevanovic, S. (2017). On-road vehicle emissions and their control in China: A review and outlook. Sci. Total Environ. 574: 332-349. https://doi.org/10.1016/j.scitotenv.2016.09.040

Xiang, S., Hu, Z.C., Zhai, W.J., Wen, D.Q. and Noll, K.E. (2018). Concentration of ultrafine particles near roadways in an urban area in Chicago, Illinois. Aerosol Air Qual. Res. 18: 895-903. https://doi.org/10.4209/aaqr.2017.09.0 347

Xiang, S., Yu, Y.T., Hu, Z. and Noll, K.E. (2019). Characterization of dispersion and ultrafine-particle emission factors based on near-roadway monitoring Part I: Light duty vehicles. Aerosol Air Qual. Res. 19: 2410 2420. https://doi.org/10.4209/aaqr.2019.08.0385

Yang, HH., Chen, H.W., Chen, C.B. and Chien, S.M. (2005). Effect of fuel properties on particulate matter and polycyclic aromatic hydrocarbon emission from diesel engine in Taiwan. Int. J. Appl. Sci. Eng. 3: 27-36. http://doi.org/10.6703/ijase.2005.3(1).27

Yang, H.H., Chien, S.M., Cheng, M.T. and Peng, C.Y. (2007). Comparative study of regulated and unregulated air pollutant emissions before and after conversion of automobiles from gasoline power to liquefied petroleum gas/gasoline dual-fuel retrofits. Environ. Sci. Technol. 41: 8471-8476. https://doi.org/10.1021/es0706495

Yao, Y.C., Tsai, J.H. and Wang, I.T. (2013). Emissions of gaseous pollutant from scooter powered by ethanolgasoline blend. Appl. Energy 102: 93-100. https://doi.org/ 10.1016/j.apenergy.2012.07.041

Zakharenko, A.M., Engin, A.B., Chernyshev, V.V., Chaika, V.V., Ugay, S.M., Rezaee, R., Karimi, G., Drozd, V.A., Nikitina, A.V., Solomennik, S.F., Kudryavkina, O.R., Xin, L., Wenpeng, Y., Tzatzarakis, M., Tsatsakis, A.M. and Golokhvast, K.S. (2017). Basophil mediated proallergic inflammation in vehicle-emitted particles exposure. Environ. Res. 152: 308-314. https://doi.org/10.1016/j.en vres.2016.10.031

Zhang, Y., Yang, L., Zhang, X., Li, J., Zhao, T., Gao, Y., Jiang, P., Li, Y., Chen, X. and Wang, W. (2019). Characteristics of $\mathrm{PM}_{2.5}$-bound PAHs at an urban site and a suburban site in Jinan in North China Plain. Aerosol Air Qual. Res. 19: 871-884. https://doi.org/10.4209/aaqr.201 8.09.0353

Received for review, April 10, 2020

Revised, April 21, 2020

Accepted, May 19, 2020 